УДК 821.35

DOI: $10.21779 / 2542-0313-2018-33-2-38-43$

\title{
А.А. Гаджиева
}

\section{Репрезентация этноментальной эстетики автора в повести Х. Авшалумова «Возмездие»}

Дагестанский государственный университет; Россия, 367001, 2. Махачкала, ул. М. Гаджиева, 43a; albinas72@mail.ru

В центре исследования лежит проблема выявления этнической эстетики автора. Художественный этнографизм, вопросы раскрытия быта и традиций получили более глубокое развитие в национальной прозе в конце XX - начале XXI в.

Каждая из них несет в себе «генетическую информацию» о народе, об эволюции художественного мышления. Писатели решают эти вопросы сквозь призму собственного мировосприятия. Раскрыть эти аспекты, показать их многосторонность и масштабность лучше всего позволяют прозаические жанры: рассказ, повесть, роман. Именно потому в основу нашего анализа легла повесть Хизгила Авшалумова «Возмездие».

Решение проблемы не может быть дано вне анализа конкретного художественного метода того или иного художника, без учета факторов этнической и ментальной самоидентификации писателей, творящих в иноязычной среде, без исследования позитивных и негативных влияний окружающей культурной среды на их самосознание. Именно через анализ отдельных ярких художественных явлений, через сопоставление весьма различных по образному строю и стилевым параметрам произведений можно обрести и некое типологически универсальное представление об основополагающих эстетических, нравственно-философских принципах литературы Дагестана.

В дагестанском литературоведении нет специальных исследований, посвященных основам этноментальности в творчестве X. Авшалумова. В ракурсе структурного подхода к поэтике произведения проведен обобщающий анализ повести татского прозаика с позиции особенностей национальной культуры.

Рассмотренные в ходе исследования детали позволяют выявить особенности этнического сознания, характер этнических мотивов и определить этническую самоидентификацию автора. Проявление национального, выстроенное автором противопоставление «мы - они» не отрицают национальных особенностей другого народа, наоборот, все произведение проникнуто чувством общенационального единства.

Ключевые слова: этноментальность, двуязычная литература, литература Дагестана, художественный этнографизм, картина мира.

Отображение в литературе национального традиционного быта принято считать художественным этнографизмом. К этнографическому материалу относятся предметы быта, одежда, национальные блюда, обычаи, обряды, праздники. Именно этим материалом и богата повесть Х. Авшалумова «Возмездие», анализ которой позволит нам выявить характер этнических мотивов и определить этноментальную эстетику самого автора.

Действие повести начинается в небольшом татском селе Нюгди в дореволюционный период, затем оно разворачивается и охватывает начало революции 1917 года. С первых же страниц читатель знакомится с обычаем вызывания дождя. По селу идет гу- 
дил: «Он с головы до ног был обвязан длинными ветками с молодыми маслянистыми листьями, что самого не было видно. Потому казалось, что по улице идет не человек, а плотная связка ветвей» [1, с. 178]. Автор дает сноску с подробным объяснением обычая: «По обычаю татов, весной, когда посевам требовалась влага, чтобы вызвать дождь, кто-нибудь в селе обряжался гудилом и ходил по дворам... Каждый должен был плеснуть на него водой со словами «дай бог дождя» и чем-нибудь отблагодарить. Обычно гудилом обряжался самый бедный, чтобы иметь заработаток» (курсив здесь и далее наш. - А.Г.) [1, с. 175]. Гудилом наряжается один из героев повести Ишмаил, вернувшийся из заключения, чтобы как-то прокормить детей. Автор, обращаясь к обычаю, рисует безысходность положения героя, его отчаяние, т. к. по его же примечанию мы узнаем о том, что гудилом наряжался только самый бедный человек. Одновременно он вводит читателя в мир традиций и обычаев своего народа.

Повесть насыщена интересными ссылками на обычаи, традиции, поверья татского народа. Так мы узнаем о божествах татов (Дедей-Ол), о том, что у татов мужчина, имевший только дочек, считался «хьоломом» - несчастным бездетным. «Чтобы обратить внимание бога на свою печальную судьбу», один из героев носит, «как велит обычай, красный кушак бездетности» [1, с. 200] и т. д. Именно таким зарисовкам быта и описанию обычаев автор отводит большую роль в понимании характеров своих героев, именно они создают атмосферу национальной жизни, которая является основой для решения художественных задач, связанных с реализацией главной идеи произведения [2].

Писатель не отказывается и от прямого повествования о жизни татов, в частности нюгдинцев: «Нюгдинцы считали для себя зазорным породниться с пастухом. Не каждый, даже самый бедный нюгдинец, согласился бы выдать свою дочь за него... как будто он в их глазах потерял мужское достоинство, опозорил честь своей папахи... Хотя нюгдинцы не отличались ни веселым нравом, ни склонностью к забавам и развлечениям, но в песне, которую они нередко распевали на свадьбах... пастух изображался как угрюмый, озлобленный и немного с придурью человек» [1, с. 185]. Так из нескольких фраз вырисовываются социальные разделения среди татов, кроме того, дана самохарактеристика: «невеселые», «не склонные к забавам».

В тексте мы встретим и такое самоопределение: «Степные и суровые нюгдинцы...» (238). Но, выявляя сквозь призму автора национальные черты татского этноса, нужно быть предельно внимательным.

Дальше в повествовании мы найдем такую характеристику одного из героев: «Обычно весельй, жизнерадостный Рахмон...», а Рахмон - представитель татского этноса [1, с. 196]. Или: «Нередко молодые нюгдинцы, когда отсутствовали старики, повинуюсь душевному порыву, лихо пускались в пляс, а остальные азартно хлопали в ладоши, подзадоривая танцующих» [1, с. 209]. «В саду, где собиралась молодежь поиграть в абаков, было шумно и весело» [1, с. 239]. Здесь есть небольшое противоречие: если таты «не склонны к забавам», почему же тогда молодежь «нередко» пускалась в пляс? Поэтому однозначно делать вывод о характере татов только лишь по первой характеристике было бы необъективно.

Хизгил Авшалумов хорошо знает культуру и традиции своего народа, эти знания тонко вплетаются в повествовательную ткань произведения. Повесть «Возмездие» помимо своей художественной ценности, помимо держащего в напряжении до последней страницы сюжета, в котором раскрываются любовные отношения героев, переплетенные с историческо-социальными явлениями, происходившими в Дагестане, является и богатым этнографическим источником. В ней отражены обычаи и традиции не только 
татов, но и всех Дагестанцев [6]. Почему же автор, описывая тот или иной обычай в сносках или прямо в тексте, указывает на принадлежность его только к татам?

«По обычаю нюгдинцев, мужчина не должен открыто выражать нежность к жене, сестре, ласкать или брать на руки ребенка при родителях или старших. Свои чувства он должен скрывать под внешней суровостью» [1, с. 236].

«Дать воды просящему, так же, как предоставить кров и постель гостю, накормить его, считалось у нюгдинцев святым делом» [1, с. 233].

Или же: «Нюгдинщь обычно рано женили своих детей, словно боясь, что их родители или дети не успеют дожить до этого счастливого события. Мальчика уже в четырнадцать лет принимали за жениха, а девушку в возрасте двенадцати-тринадцати лет нередко выдавали замуж» [1, с. 197].

«Нередко девушка, прежде чем наполнить свой кувшин, склонялась над водой и долго разглядывала себя в ней, как в зеркале, которое было редкостью в домах у нюгдиниев» [1, с. 232].

Читатель, если он житель Дагестана, сразу понимает, что вышеперечисленное относится не только к представителям татского этноса. Проявление строгости к близким в присутствии взрослых свойственно всем нациям Дагестана, оно сохраняется и по нынешнее время. К тому же так рано женили и выдавали замуж во всем Дагестане, не только у татов, и закон гор - закон гостеприимства был у всех. Зеркала же могли позволить себе женщины только из богатых семей, и неважно, какой они были национальности.

Можно было бы сослаться на какие-то оговорки, накладки, если бы указанные эпизоды были единственными в повести, но это не так. Известные каждому дагестанцу обычаи (предоставить платок после первой ночи как знак целомудрия невесты, бросить платок к ногам мужчины - мольба прекратить конфликт со стороны женщины и другие) даны со сносками, начинающимися со слов: «По обычаю татов...»

Автора нельзя упрекнуть в том, что это не так. Конечно, все эти обычаи есть у татов. И он вправе не обобщать: по обычаям Дагестана, а конкретизировать. Но интересно то, что подобные сноски производятся, когда речь идет не только об обычаях, но и о законе, не имеющем отношения к традициям и распространяющемся на весь Дагестан. Говоря о батраке, которого уберегли от мобилизации в царскую армию, автор дает сноску: «Tаты подлежали мобилизации в царскую армию» [1, с. 237]. Разве только таты призывались в армию?

Здесь мы сталкиваемся с субъективированной формой проявления этничности этническим самосознанием - «чувством принадлежности к тому или иному этносу, выражающиеся в этническом самоопределении, то есть в отнесении индивидом себя к данной этнической группе» $[4$, с. 56]. Иными словами, этническое самосознание - это восприятие этносом самих себя в антитезе «мы - они»: мы - таты, они - другие.

Такое противопоставление «мы - они» у Х. Авшалумова проявляется и в определении одного из персонажей повести, который пришел из другого села: «Открываю глаза, вижу: передо мной стоит лезгин Гасан» [1, с. 225]. «...То был лезгин Гасан» [1, c. 227]. Хизгил Авшалумов двуязычный писатель. И эта повесть вначале вышла на татском языке, потом была переведена им и издана на русском. На родных языках при определении человека не своей нации для уточнения используется определение, или его национальности, или вид его деятельности (сапожник Ильяс), или же его физический недостаток (хромой Ильяс) без оценочных оттенков.

Эту же особенность заметил и использовал в повести «Хаджи-Мурат» Лев Толстой, проживший на Кавказе долгое время и изучавший языки тюркской группы. В по- 
вести часто использует такое определение для одного их своих героев: «авареи Ханафи», таулинеи Ханафи [2, с. 20]. В отличие от Х. Авшалумова, толстовское определение - это не проявление этничности автора, а проявление двуязычия, т. е. влияния языкового стиля жителей определенной местности на родной язык человека, изучающего их язык.

Оппозиция «мы - они» в наших наблюдениях - это проявление этнической идентификации, но если быть точнее и учитывать характер возникновения противопоставления, то сюда включается и добавочное действие - ситуативная идентификация ${ }^{1}$. Наш двуязычный автор, зная, что его произведения будут читать и за пределами Дагестана, решил представить свой народ в таком богатом контексте.

Взаимодействие и взаимовлияние языков приводит к взаимообогащению и взаимопроникновению культур, и это не требует доказательств. В произведении двуязычного автора Хизгила Авшалумова представлен богатый материал культуры татского народа, связанный с их этническим самосознанием. Безэквивалентная лексика в произведении национального писателя отличается семантической детализацией. При анализе наблюдается стремление автора полнее ознакомить реципиента с особенностями жизни, быта, психологией своего народа, а также с его языком. Он использует национальную лексику для обозначения предметов быта, одежды, древних обычаев. Употребление подобной лексики создает национальную маркированность текста, что еще раз подчеркивает желание автора в полном объеме донести до читателя культуру, традиции, мировоззрение, характер своего народа [8].

Картина мира в художественном тексте создается языковыми средствами. Выбор тех или иных языковых средств, целиком зависит от индивидуальной картины мира самого автора, и проявляется в отборе элементов содержания художественного произведения [9]. Обращение Х. Авшалумова к таким строевым единицам языка, как пословицы и поговорки, позволяет предать местный колорит. С другой стороны, они позволяют демонстрировать бытовые, социальные, философские, морально-этические и другие взгляды своего народа, т. к. назначение пословиц - дать народную оценку объективных явлений действительности, выражая его мировоззрение. К примеру: «На пашне мечтаний растет лишь ослиный навоз» [1, с. 176]. «Ворон ворону глаз не выклюет» [1, с. 202]. «Несчастного волк даже с горба верблюда достанет» [1, с. 217]. «Беки дерутся, а у нукеров головы летят» $[1$, с. 256]. «Если хочешь поймать жеребенка, нечего перед ним кидать вверх папаху» [1, с. 262] и др. Пословицы и поговорки тесно связаны с культурой, и использование их в тексте позволяет отразить глубокое чувство национальной культуры народа.

Через рассмотренные нами детали проявляются элементы этнического сознания, этнической идентификации. Именно так человек ощущает сопричастность к своему роду, осознает субъективную, социально-психологическую привязанность к объективно существующим компонентам этнической реальности [3]. В силу этого человек формирует «образ Я - этнического субъекта», представителя определенной этнической общности. Однако этническая идентичность - это не только осознание своей тождественности с этнической общностью, но и оценка значимости членства в ней. Помимо этого она даёт человеку наиболее широкие возможности для самореализации. Эти возможно-

\footnotetext{
${ }^{1}$ Инструментализм (от лат. instrumentum - орудие) - сложившийся в зарубежной науке в 70-е годы XX века подход, рассматривающий этнос и этничность как инструмент для достижения различными элитами, группами или отдельными людьми каких-то своих целей (экономического, политического или иного характера). Например, для повышения своего социального статуca, удовлетворения потребностей, борьбе за власть и привилегии.
} 
сти опираются на эмоциональные связи с этнической общностью и моральные обязательства по отношению к ней [4].

Тесная эмоциональная связь, любовь к своему народу, знание его культуры и традиций, истории, гордость за него и побудили Хизгила Авшалумова выразить национальную сущность своего народа, его миропонимание в близких его художественному сознанию формах. «Авшалумов - тат. Это обстоятельство, несомненно, отражается в его произведениях. Психология горского еврея формировалась под влиянием социальных перемен в жизни дагестанских народов. Ведь история дагестанских народов - это история татов. Сам X. Авшалумов неоднократно выступал в печати, доказывая историческую общность татов с другими народностями Дагестана» [5, с. 158].

Поэтому, несмотря на ярко выраженное проявление этнической идентификации, автор с глубоким уважением относится к представителям других этносов, которые по мере художественной необходимости появляются в повести: это лезгины и армяне, тесно контактирующие с татами в силу своей географии. Мотив дружбы между этими народами прослеживается по всей повести. «Первые дни после бегства из родного села Сосун, скрываясь от властей, нашел себе убежище в доме лезгина Гасана, у которого среди нюгдинцев было много своих кунаков - друзей» [1, с. 289]. Стоит обратить внимание на одну деталь. Если ранее в тексте автор не давал сносок слову «кунак», возможно, потому, что для жителей всего Северного Кавказа оно хорошо знакомо, то в данном тексте он его нарочито переводит, и оно становится понятным для всех, кто прочтет это произведение и поймет главное: народы Дагестана дружат.

Чувства сопереживания и сочувствия к чужой беде возникают без разделения на нации, без разницы в вероисповедании: «Хотя никто из них (жителей Нюгди) даже не представлял себе, где, в какой части света находится столичный город Петербург, но в эту минуту было такое чувство, словно горе русских рабочих было их собственным горем» $[1$, с. 209].

В анализируемой повести X. Авшалумову удалось донести до читателя особенности мировоззрения, характера своего народа, рассказать о его культуре и традициях, сохранив при этом чувство общенационального единства.

\section{Литература}

1. Авшалумов Х. Сказание о любви // Возмездие. - Махачкала, 1965.

2. Николаев П.А., Руднева Е.Г., Хализев В.Е. Теория литературы. - 2-е изд. - М., 1998.

3. Гаджиева А.А. Тюркизмы в повести Л. Толстого «Хаджи-Мурат» // Вопросы тюркологии. - 2010. - № 5. - Махачкала. - С. 19-23.

4. Абуков К.И. Разноязычное единство: обретения и потери // Национальные литературы в системе взаимосвязей и поиске собственных путей развития. - Махачкала, 1992.

5. Ахмедов C.M. Художественная проза народов Дагестана: история и современность. - Махачкала, 1996.

6. Хуm М.P. Экспликация ментальных характеристик этноса в тексте билингвальной языковой личности // Вестник Майкопского государственного технологического университета. - 2013. - Вып. 2. - С. 33-38.

7. Нефедова Л.Н. Особенности организации художественной картины мира у авторов-билингвов. URL: https://cyberleninka.ru/article/n/osobennosti-organizatsiihudozhestvennoy-kartiny-mira-u-avtora-bilingva (дата обращения: 08.01.2018).

8. Мазанаев Ш.А. Двуязычное художественное творчество в системе национальных литератур. - Махачкала, 1997. 
9. Анзорова С.П. История и педагогика естествознания // Билингвизм - двуязычие и бикультурность: история и современность. - 2014. - Вып. 3. - С. 78-80.

10. Буралова Р.А. Филологические науки. Вопросы теории и практики // К вопросу о «сбалансированном» и национально-русском двуязычии и билингвизме. -2018. - Вып. 3. - С. 45-56.

11. Джавадова Л.Д. Историческая и социально-образовательная мысль // Художественное воплощение национального характера и фольклорных традиций в лезгинской прозе. - 2018. - Вып. 4. - С. 67-79.

Поступила в редакциию 23 мая 2018 г.

\title{
UDC 821.35
}

DOI: $10.21779 / 2542-0313-2018-33-2-38-43$

\section{Representation of author's ethnic and mental aesthetics in the novel «Retribution» by Hizgil Avshalumov}

\author{
A.A. Gadjieva \\ Dagestan State University; Russia, 367001, Makhachkala, M. Gadzhiev st., 43 a; \\ albinas72@mail.ru
}

The focus of the study lies on the problem of identifying the ethnic aesthetics of the author. Artistic ethnographism, the disclosure of everyday life are analysed deeply the development in the national prose in the end of XX - the beginning of XXI centuries.

Each of them carries "genetic information" about people, about the evolution of artistic thinking. Writers solve these issues through the prism of their own worldview. To reveal these aspects, to show their versatility and scale such prose genres as the story, the long story, the novel are most appropriate. It is because the basis of our analysis laid the story Hishila Avshalumova "Retribution".

The solution to the problem cannot be given without the analysis of a particular artistic method of an artist, without taking into account the factors of ethnic and mental self-identification of writers who create in a foreign language environment, without studying the positive and negative effects of the cultural environment on their self-consciousness. It is through the analysis of some bright artistic phenomena, in comparison of very different in the figurative structure and style parameters of works that it is possible to find a certain typologically universal idea of the fundamental aesthetic, moral and philosophical principles of Dagestan literature.

In the Dagestan literary criticism there is no special research on ethnic mentality in Avshalumov's works. From the perspective of the structural approach to the poetics of the work, a generalizing analysis of the novel by the Tat writer from the perspective of the national culture features is carried out.

The details considered in the course of the study allow to reveal the features of ethnic consciousness and the nature of ethnic motives and also to determine the author's ethnic selfidentification. The revealed features of the national manifestation, the opposition "We - They" built by the author does not deny the national features of another people, on the contrary, the whole work is full with a sense of national unity.

Keywords: ethnic mentality, bilingual literature, Literature of Dagestan, artistic ethnography, picture of the world.

Received 23 May, 2018 